\title{
Development of homologous radioimmunoassays for equine growth hormone and equine prolactin and their application to the detection of circulating levels of hormone in horse plasma
}

\author{
CM Cahill ${ }^{*}$, H Van der Kolk ${ }^{2}$, JA Goode ${ }^{3}$, TJ Hayden ${ }^{1}$ \\ 1 Department of Zoology, University College Dublin, Belfield, Dublin 4, Ireland; \\ 2 Department of Large Animal Medicine and Nutrition, Faculty of Veterinary Medicine, \\ Utrecht University, The Netherlands; \\ ${ }^{3}$ AFRC, Institute of Animal Physiology and Genetics Research, Babraham, \\ Cambridge CB2 4AT, UK
}

(Received 14 December 1993; accepted 25 April 1994)

\begin{abstract}
Summary - Highly purified and well-characterised preparations of equine prolactin and growth hormone from equine pituitary glands were employed to set up highly sensitive and specific homologous radioimmunoassays (RIA) for the measurement of hormone in horse plasma. The limit of sensitivity of the GH RIA was $1.2 \mathrm{ng} / \mathrm{ml}$ with mean intra- and inter-assay coefficients of variation (CV) of 6.6 and $10 \%$, respectively. The sensitivity of the equine prolactin (ePRL) RIA was $0.5 \mathrm{ng} / \mathrm{ml}$ with mean intra and inter-assay CV of 9.1 and $15.6 \%$, respectively. Dose-response curves of a crude pituitary gland extract and plasma samples collected from a mare and foal were parallel to the standards and the PRL. RIA was clinically validated by administration of thyrotropin-releasing hormone (TRH). Plasma samples taken at $15 \mathrm{~min}$ intervals over $24 \mathrm{~h}$ from lactating mares gave $24 \mathrm{~h}$ mean $\mathrm{GH}$ values in the range 5.5 to 7.95 $\mathrm{ng} / \mathrm{ml}$. Large intermittent elevations of $\mathrm{GH}$ activity were detected. The mean $24 \mathrm{~h} \mathrm{PRL}$ concentrations were between $3.2-10.4 \mathrm{ng} / \mathrm{ml}$ in the lactating animals, with higher concentrations earlier in lactation. Long episodic bursts of PRL were detected.
\end{abstract}

equine / purification / characterisation / radioimmunoassay / equine prolactin / equine growth hormone

Résumé - Mise au point de tests radio-immunologiques homologues pour la détection de l'hormone de croissance et de la prolactine équines et leur application pour la détection des concentrations d'hormones circulantes dans le plasma de cheval. La prolactine $(P R L)$ et l'hormone de croissance (GH) ont été purifiées à partir d'hypophyses de cheval. Ces préparations d'hormones ont permis de préparer des anticorps spécifiques et de mettre au point des tests de RIA homologues. La limite de détection du RIA de l'hormone de croissance est de $1.2 \mathrm{ng} / \mathrm{ml}$, avec des moyennes de coefficients de variations (CV) inter-et intra-tests de 6,6\% et $10 \%$ respectivement. La sensibilité du RIA et

Present address: Dana Farber Cancer Institute, Jimmy Fund Lab 205, Harvard Medical School, 44 Binney St, Boston MA 02115, USA 
de la PRL est de $0,5 \mathrm{ng} / \mathrm{ml}$ avec une moyenne de CV inter-et intra-tests de respectivement $9,1 \%$ et $15,6 \%$. Les courbes d'effet-dose d'extrait brut d'hypophyse et d'échantillons de plasma prélevés sur une jument et un poulain sont parallèles aux courbes standard et le RIA de la PRL a été validé cliniquement par injection de la "thyrotropin releasing hormone" (TRH). Des niveaux de GH à $24 \mathrm{~h}$ de 5,5 à $7,95 \mathrm{ng} / \mathrm{m} /$ de $\mathrm{GH}$ ont été détectés dans des échantillons de plasma de juments allaitantes prélevés à 15 min d'intervalle sur une période de $24 \mathrm{~h}$. Des variations élevées, courtes et intermittentes de GH ont été détectées. Les concentrations moyennes à $24 \mathrm{~h}$ de $P R L$ se situent entre 3,2 et $10,4 \mathrm{ng} / \mathrm{ml}$ pendant la lactation, avec des niveaux plus élevés dans les phases précoces de lactation avec de longs pics épisodiques.

équin / purification / particularité / dosage radio-immunologique / prolactine / hormone de croissance

\section{INTRODUCTION}

Prolactin (PRL) and growth hormone (GH) are protein hormones produced in the anterior pituitary gland, which are involved either directly or indirectly in growth and lactation in all mammalian species. Although equine GH (eGH) has been purified (Saxena and Henneman, 1966; Hartree et al, 1968; Conde et al, 1973) and antisera have been raised in rabbits (Poskus et al, 1976) inadequate supplies of the hormone have precluded the development of a homologous radioimmunoassay (RIA) for its measurement. A role for eGH in the anabolic process of foal growth is presumed and a galactopoietic role similar to that in ruminants has been suggested (Worthy et al, 1986). The purification of equine PRL (ePRL) has been previously described (Chen et al, 1979; Li and Chung, 1983) and there are several RIAs available for its measurement (Roser et al, 1984; Johnson, 1986; Thompson et al, 1986a; Worthy et al, 1986). Prolactin is likely to control the growth and function of the mammary gland during a normal gestation and lactation (Worthy et al, 1986) and may also be involved in ovarian function in the mare (Roser et al, 1987). It has also been suggested that PRL may be involved in infertility post partum (Worthy et al, 1986). Here we report the development of homologous RIA for each hormone and their application to physiological samples in the horse with particular emphasis on lactation.

\section{MATERIALS AND METHODS}

\section{Purchased supplies}

Sodium ${ }^{125}$-iodide and ${ }^{35} S$ were purchased from Amersham PLC UK; lodogen, Pierce Laboratory Rockford, IL, USA; ampholine PAG plates, diethylaminoethyl (DEAE) sephacel, phenyl sepharose CL-4B, sephadex G-100, and molecular weight markers were purchased from Pharmacia, Milton Keynes UK; tissue culture media, Gibco Biocult, Paisley, Scotland; JB-4 resin kit, Polysciences Inc, Warrington, PA, USA; thyrotropinreleasing hormone, bovine serum albumin, adjuvants and reagents for PAGE, Sigma Chemical Co, Poole, Dorset UK; lithium heparin blood sampling tubes $(100 \times 16 \mathrm{~mm})$, intravenous cannulae (Branula G-14 and vygon mosquitos $123 \mathrm{G}$ $13,70 \mathrm{~mm}$ ), Biovet, Mullingar, Rep of Ireland; donkey anti-guinea-pig gamma globulin, Guildhay Antisera Ltd, Guildford, Surrey, UK.

\section{Hormones and reagents}

Ovine PRL (NIAMDD-oPRL-14, $31 \mathrm{iu} / \mathrm{mg}$ ), bovine PRL (NIAMDD-bPRL-6, $30 \mathrm{iu} / \mathrm{mg}$ ), ovine $\mathrm{GH}$ (NIH-oGH-S-11, $0.56 \mathrm{iu} / \mathrm{mg})$, bovine $\mathrm{GH}(\mathrm{NIH}$ bGH-B-18, $0.81 \mathrm{iu} / \mathrm{mg}$ ), rat PRL (NIDDK-rPRLB-6,2 iu/mg), rat GH (NIDDK-rGH-B-12, $1.8 \mathrm{iu} / \mathrm{mg}$ ) were obtained from the NIAMDD, Baltimore, MA, USA; porcine PRL (USDA pPRL-B-1, $34 \mathrm{iu} / \mathrm{mg}$ ) and porcine $\mathrm{GH}$ (pGH-B-1, $1.5 \mathrm{iu} / \mathrm{mg}$ ), were obtained from D Bolt at the USDA, Beltsville, MA, USA; human GH (MRC 1st International Standard for immunoassay B 66/217). The equine gonadotrophin fraction was obtained from M Kelly, Faculty of Agriculture, University College Dublin 
and was a $150 \mathrm{mM}$ ammonium sulphate, $\mathrm{pH} 4$ extract from equine pituitary glands. The equine pituitary extracts were alkaline extracts $(100 \mathrm{mM}$ ammonium acetate, $\mathrm{pH}$ 8.5) dialyzed and lyophilized from whole equine pituitary glands.

\section{Animals}

Pigeons of mixed breed and sex (adults, aged over 2 years and weighing between 298 and $537 \mathrm{~g}$ ) were obtained from the Department of Psychology, Thornfield, University College Dublin. They were housed under uniform temperature conditions $\left(25-26^{\circ} \mathrm{C}\right)$ in a room artificially illuminated during the normal daylight hours. They were kept for at least 1 week before being used in assays and were caged in pairs and fed pigeon chow and water ad libitum. Albino Schofield mice were obtained from Trinity College Dublin and were maintained as a randomly bred colony for at least 9 generations before experimental use. Snell dwarf mice were obtained from AT Holder and were maintained as a breeding colony at the animal facility at the NIRD Shinfield, Reading.

\section{Tissue sources}

Pituitary glands were collected from horses of mixed breed (Irish horse abbatoir, Straffan, Co Kildare) and were frozen immediately in liquid nitrogen and stored frozen at $-20^{\circ} \mathrm{C}$ until use. Livers and mammary glands were collected from rabbits (Western Laboratories Ltd) and mares (Irish horse abattoir) and were kept at $-20^{\circ} \mathrm{C}$ for up to 3 months before preparation of microsomes for radioreceptor assays (RRAs).

\section{Extraction of $\mathrm{GH}$ and $P R L$ from equine pituitary glands}

\section{Growth hormone}

Extraction of the hormone from horse pituitary glands was by the general extraction procedure for pituitary hormones (Licht et al, 1977). Pituitary glands were homogenized in 5 volumes $25 \mathrm{mM}$ ammonium bicarbonate, $\mathrm{pH} 9.0$ and extracted for $2 \mathrm{~h}$ at $4^{\circ} \mathrm{C}$. Following centrifugation
(10 000 $\mathrm{g}$ for $15 \mathrm{~min}$ ) the residue was re-extracted as above and the pellet discarded. The pooled supernatants were brought to $0.15 \mathrm{M}$ ammonium sulphate, adjusted to $\mathrm{pH} 4.0$ and stirred for $1 \mathrm{~h}$ at $4^{\circ} \mathrm{C}$. After centrifugation as described above the supernatant was discarded and the residue containing the $\mathrm{GH}$ (Farmer et al, 1975), PRL and adrenocortico-trophic hormone was resuspended in $50 \mathrm{mM}$ ammonium acetate $(155 \mathrm{ml}) \mathrm{pH} 9.5$.

\section{Prolactin}

Equine PRL was prepared from horse pituitary glands by the method of $\mathrm{Li}$ and Chung (1983) (with modifications). Acid-acetone powder $(9.5 \mathrm{~g}$ ) was extracted overnight in $0.1 \mathrm{M}$ ammonium acetate, $\mathrm{pH}$ 9.5. The insoluble material was removed by centrifugation at $9500 \mathrm{~g}$ for $20 \mathrm{~min}$ and the supernatant was adjusted to $\mathrm{pH}$ 5.7. The isoelectric precipitate was recovered by centrifugation and dissolved in $25 \mathrm{mM}$ ammonium acetate, pH $9.5(150 \mathrm{ml})$. Aliquots $(50 \mathrm{ml})$ were stored frozen at $-20^{\circ} \mathrm{C}$.

\section{Electrophoretic characterisation}

SDS polyacrylamide gel electrophoresis was carried out as described previously (Laemmli, 1970). Discontinuous polyacrylamide gel electrophoresis was carried out as described by Davis (1964) Isoelectrofocusing was carried out on ready-made acrylamide gels (5\% acrylamide, $3 \%$ bis-acrylamide) in the $\mathrm{pH}$ range 3.5-9.5. Hormone samples $(20 \mu \mathrm{g})$ in $1 \%$ glycine were focused at $10^{\circ} \mathrm{C}$ for $1.5 \mathrm{~h}$ at $30 \mathrm{~W}, 1500 \mathrm{~V}$ and $50 \mathrm{~mA}$ (LKB 2103 power supply settings). The $\mathrm{pH}$ gradient was determined using a surface $\mathrm{pH}$ electrode.

\section{Bioactivity}

Standard ovine PRL (OPRL) and bovine GH (bGH) RRAs were set up to characterise the binding activity of $\mathrm{ePRL}$ and $\mathrm{eGH}$ to lactogenic and somatogenic receptors. Microsomal membranes from lactating rabbit mammary gland, pregnant mare mammary gland and pregnant rabbit liver (Shiu et al, 1973; Tsushima and Friesen, 1973) and plasma membranes from rabbit and mare liver were used (Parke and Forsyth, 1975). Mouse mammary gland bioassay was carried out as described by Hayden et al, 1991, and the local or micro method of pigeon crop sac bioassay was 
used (Nicoll, 1967), The Snell dwarf mouse bioassay was carried out as described by Holder et al (1980).

\section{Immunoactivity}

The crossreactivity of $\mathrm{eGH}$ was examined in an homologous pGH RIA (Buttle, 1987a). The crossreactivity of ePRL was examined in an homologous ePRL RIA (Worthy et al, 1986) and in an homologous pPRL RIA (Buttle, 1987b).

\section{Assay development and validation}

\section{Radioiodinations}

Equine $\mathrm{GH}$ and ePRL $(5 \mu \mathrm{g})$ were radiolabelled with $\mathrm{Na}{ }^{125}$ ( $\left.0.5 \mathrm{mCi}\right)$ by the lodogen method (Salacinski et al, 1981). Labelled hormone was separated from free iodine by gel filtration chromatography on Sephadex G-100 previously coated with a solution of $0.5 \%$ BSA in RIA buffer. The specific activity, estimated by self-displacement analysis (Abdul-Ahad, 1984) was $36 \pm 7.9$ (sd) $\mu \mathrm{Ci} / \mu \mathrm{g}(n=6)$ for ePRL and $41.5 \pm 10$ (sd) $\mu \mathrm{Ci} / \mu \mathrm{g}(n=5)$ for $\mathrm{eGH}$.

\section{Growth hormone}

Antisera were raised in 2, 4-month-old Duncan Hartley strain guinea pigs with 3 , monthly, subcutaneous injections of 750-950 $\mu \mathrm{g}$ of eGH each, emulsified in Freunds incomplete adjuvant. A final boost of $215 \mu \mathrm{g}$ was given and the animals were bled by cardiac puncture 2 weeks later. Titre studies indicated that the dilution of antibody that bound $60 \%$ of the $125 \mathrm{I}-\mathrm{eGH}$ in the absence of competitor was 1:10 000 (final). One set of antisera was of higher affinity and this was employed in the RIA. The antiserum was used at a final dilution of 1:10 000. All dilutions were made up in RIA buffer ( $50 \mathrm{mM}$ sodium phosphate, $\mathrm{pH} 7.5$, containing $0.5 \% \mathrm{BSA}$ and $150 \mathrm{mM} \mathrm{NaN}_{3}$ ). The assay tubes contained dilutions of standard eGH $(0.98-250 \mathrm{ng} / \mathrm{ml}$ in $100 \mu \mathrm{l})$, or of plasma sample (1:2 and 1:4), antiserum (100 $\mu \mathrm{l})$ and ${ }^{125} \mathrm{l}-\mathrm{eGH}$ $(20000 \mathrm{cpm}$ in $50 \mu$ ). The antibody was allowed to preincubate with the standard for $48 \mathrm{~h}$ before addition of the tracer and incubation overnight at $4^{\circ} \mathrm{C}$. This was followed by the addition of normal guinea-pig serum $(50 \mu$, diluted 1:700) and donkey anti-guinea-pig gamma globulin $(50 \mu$, diluted
1:56). After incubation for a further $24 \mathrm{~h}$, separation of the precipitated (bound) and free radioactivity was achieved by adding $1 \mathrm{ml}$ of a cold $4 \%$ solution of polyethylene glycol in phosphatebuffered saline and centrifugation at $2500 \mathrm{~g}$ for 30 $\min$ at $4^{\circ} \mathrm{C}$. The supernatant fraction was drained and the antibody bound hormone in the precipitate was counted on an automatic 1260 multigamma 11 counter ( $74 \%$ efficiency).

\section{Administration of hGRF $_{(1-29)}$}

Three Dutch warm-blooded mares between 8 and 18 years of age and weighing between 463 and $546 \mathrm{~kg}$ were used. The animals were used in a 2-factor cross over design. One horse was injected with $670 \mu \mathrm{g}$ hGRF $_{(1-29)}$ (Kabivitrum $r$, Stockholm, Sweden) dissolved in $5 \mathrm{ml}$ saline intravenously and the other 2 were given the equivalent volume of saline. The next day each horse was given the opposite treatment. Blood samples were collected from the left jugular vein via an indwelling catheter at various times before and after administraton of saline or hGRF (1-29) .

\section{Effect of fasting on GH concentrations}

Six Dutch warm-blooded horses ( 3 mares and 3 geldings) between 9 and 12 years of age and weighing between $580-634 \mathrm{~kg}$ were used. Blood samples $(5 \mathrm{ml})$ were collected from the jugular vein by venepuncture at $10.00,10.30,11.00$, 11.30 and $12.00 \mathrm{~h}$ prior to fasting and at the same time points after $16 \mathrm{~h}$ fasting.

\section{Prolactin}

Antisera to ePRL were raised in 2, 3-month-old New Zealand White rabbits using 3 injections of approximately $350 \mu \mathrm{g}$ ePRL at $2-3$ week intervals, in Freunds complete adjuvant for the first injection and incomplete adjuvant subsequently. The antisera bound between 40 and $60 \%$ of 125 ePRL at a final dilution of 1:5 000 and further immunizations failed to boost greater responses. Both antisera revealed similar specificities and affinities and they were pooled.

All assay reagents were made up in RIA buffer. The assay tubes contained dilutions of standard ePRL $(0.48-250 \mathrm{ng} / \mathrm{ml}$ in $100 \mu \mathrm{l})$ or plasma samples (1:2 and 1:4), antiserum (100 $\mu \mathrm{l})$ and $125 \mathrm{l}$-ePRL $(20000 \mathrm{cpm}$ in $50 \mu \mathrm{l})$. The sensi- 
tivity of the assay was increased by preincubating the standard with antibody for $72 \mathrm{~h}$ before addition of tracer. Incubation was at $4^{\circ} \mathrm{C}$ and was followed by the addition of normal rabbit serum $(50 \mu)$, diluted 1:700) and sheep anti-rabbit gamma globulin $(50 \mu \mathrm{l}$, diluted $1: 28)$. The assay was completed as described above.

\section{Administration of TRH}

To determine if the PRL RIA detected changes in PRL concentrations in plasma in response to $\mathrm{TRH}$, bload samples were taken from each of 3 animals (a non-lactating mare, a lactating mare and a stallion) via indwelling jugular catheters implanted $24 \mathrm{~h}$ before TRH injection $(2.34 \mathrm{mg}$ in $1 \mathrm{ml}$ of sterile saline, administered intravenously). A lactating mare received an injection of saline only. Blood was collected at 15 min intervals from -60 to $+165 \mathrm{~min}$ relative to injection.

\section{Twenty-four-hour profiles of growth hormone and prolactin}

Blood samples were taken at $15 \mathrm{~min}$ intervals for at least $24 \mathrm{~h}$ into heparinized tubes from an indwelling jugular catheter implanted $24 \mathrm{~h}$ before sampling. Two Connemara ponies (\#101, age unknown, and \#105, age 14 years) and 3 crossbreeds (throughbred $x$ |rish draught, \#102, \#103 and \#104) ranging in age from 9 to 20 years. Mares \#101, \#102 and \#103 were lactating. Sampling times were as follows: (1) \#101, week 1 of lactation from 6-7 March (starting at $06.45 \mathrm{~h}$ on d1 to $07.15 \mathrm{~h}$ on $\mathrm{d} 2$ ), week 3, from 22-23 March (06.30 h on d1 to $07.00 \mathrm{~h}$ on $\mathrm{d} 2$ ) and week 6 , from 16-17 April (06.45 h on d1 to $07.15 \mathrm{~h}$ on d2); (2) \#102, week 1 of lactation, 23-24 May (10.15 h on d1 to $10.30 \mathrm{~h}$ on d2) and week 8 , 14-15 July ( $10.15 \mathrm{~h}$ on d1 to $10.30 \mathrm{~h}$ on d2); and (3) \#103, week 2 of lactation (sampled in May as described). Horse \#104 was a non-lactating mare and \#105 was a stallion (sampled in mid-July as described). Plasma was collected by centrifugation at $1500 \mathrm{~g}$ for $20 \mathrm{~min}$ and stored at $-20^{\circ} \mathrm{C}$ until assay. Animals were subjected to the natural photoperiod, temperatures and feeding regimes throughout the period of study.

\section{Statistical analysis}

RRA and RIA dose-reponse curves were analyzed using the computerized, non-linear, least- squares curve fitting routine (Allfit) of De Lean et af (1978). Potency estimates of the hormones were obtained using the $\mathrm{ED}_{50}$ values $(50 \%$ maximally effective dose). In the mouse mammary gland bioassay, the relationship between the lactogenic hormone concentration of the medium and the secretory grades of the explants were evaluated by linear regression analysis and by the Bonferroni $t$-test (Gill, 1986) to determine if hormonally stimulated effects were significant. Validity tests were carried out on the results of the pigeon crop sac bioassay using the methods for the 6-point parallel line assay of Wardlaw (1985). Potency estimates and $95 \%$ confidence limits were made using the method of Finney (1978) employing slope and variance in the final calculations. Results of the assay of plasma samples were calculated using the RIA program of the 1260 multigamma 2 counter based upon cpm versus log concentration. A paired t-test and a sign test were used to determine the significance of the timing or the $\mathrm{GH}$ concentration of the $\mathrm{GH}$ peak in the GRF challenge test. The Hotelling's $T^{2}$ statistic was used to determine if $\mathrm{GH}$ concentrations differed with feeding status (Morrison, 1967; Rosner, 1990).

\section{RESULTS}

\section{Isolation of equine $\mathrm{GH}$ and equine PRL}

\section{Growth hormone}

Table I summarises the steps involved in the purification of eGH. The initial $\mathrm{pH} 9$ extract had quite a low specific activity relative to bGH in the RRA. This was followed by an ammonium sulphate-assisted acid precipitation of the $\mathrm{GH}$ resulting in a 5 -fold increase in the purity of eGH and $50 \%$ recovery of $\mathrm{GH}$-like activity. The specific activity of this fraction relative to bGH was 0.27 . Growth hormone eluted from a sephadex G-100 column with a KaV of 0.416 and a $V_{\mathrm{e}} / V_{0}$ ratio of 2.25. Gel filtration resulted in a 2.3-fold purification over the previous step and a specific activity of 0.57 . The elution profile of eGH from phenyl sepharose was rather broad, eluting 
Table I. Summary of purification of eGH from a $50 \mathrm{~g}$ wet weight of equine pituitary glands.

\begin{tabular}{lccccc}
\hline Fraction & $\begin{array}{c}\text { Total bGH } \\
\text { equiv }(\mathrm{mg})+\end{array}$ & $\begin{array}{c}\text { Protein } \\
(\mathrm{mg})\end{array}$ & $\begin{array}{c}\text { Specific activity } \\
(\mathrm{mg} / \mathrm{mg})+\end{array}$ & $\begin{array}{c}\text { Purification } \\
\text { (fold) }\end{array}$ \\
\hline pH 9 ammonium bicarbonate extract & 259.8 & 5929 & 0.043 & - \\
pH 4 ammonium sulphate precipitate & $130.7(50.3)$ & 546 & 0.240 & $5.58(5.6)$ \\
Post-gel filtration & $75.4(57.7)$ & 132.3 & 0.571 & $13.27(2.4)$ \\
Post-hydrophobic interaction chromatography & $31.9(42.3)$ & 48 & 0.66 & $15.44(1.2)$ \\
Post-anion exchange chromatography & $28.0(87.9)$ & 25.5 & 1.1 & $25.58(1.7)$ \\
& & & & & \\
\hline
\end{tabular}

Values in parentheses are relative to the preceding step; +: by radioreceptor assay.

between $90 \mathrm{mM}$ and $38 \mathrm{mM}$ ammonium acetate (fig 1A). Active fractions were pooled and corresponded to $42 \%$ of the $\mathrm{GH}$ applied, a 1.2-fold increase in purity over the previous step and a specific activity of 0.66 . Ion exchange chromatography was highly efficient in separating the PRL from the $\mathrm{GH}$. Growth hormone was eluted in 2 broad bands, one was unadsorbed by the gel and was free of equine PRL (fig 1B) and the other was eluted between $0.06 \mathrm{M}$ and 1.45 $M$ sodium chloride. Only the breakthrough fractions were pooled and contained $88 \%$ of the $\mathrm{GH}$ activity applied with a specific activity of 1 and an overall yield of $0.5 \mathrm{mg}$ $\mathrm{GH}$ per $\mathrm{g}$ of fresh pituitary glands.

\section{Prolactin}

Table II summarises the purification of ePRL. Substantial losses of up to $65 \%$ of
oPRL-like RRA activity were detected after isoelectric precipitation of ePRL. This was prevented in later runs by standing the extract for up to $48 \mathrm{~h}$ at $4^{\circ} \mathrm{C}$ and reharvesting the precipitate. On a sephadex-G 100 column ePRL was eluted as a single peak with an elution volume 2.1 times that of the void volume $\left(V_{\mathrm{e}} / V_{0}=2.1\right)$ corresponding to a KaV of 0.4 (fig $1 \mathrm{~B}$ ) resulting in a 2.5 -fold increase in purity and over $60 \%$ recovery relative to the preceding step. Equine $P R L$ eluted from the ion exchanger at $0.1 \mathrm{M}$ sodium chloride and yielded almost $90 \%$ of the applied hormone. An increase of 4-fold in purity over the product of the previous. step was achieved, giving an overall purity of 10-fold. The low potency of the final preparation of $\mathrm{PPRL}$ relative to oPRL in all of the lactogenic RRAs ( $<2 \mathrm{iu} / \mathrm{mg}$ ) precluded their use as quantitative assays. The rabbit mammary gland RRA was therefore used

Table II. Summary of purification of ePRL from a $500 \mathrm{~g}$ wet-weight batch of equine pituitary glands.

\begin{tabular}{llccr}
\hline Fraction & $\begin{array}{c}\text { Total ovine } \\
\text { PRL equiv }(\mathrm{mg})+\end{array}$ & $\begin{array}{c}\text { Protein } \\
(\mathrm{mg})\end{array}$ & $\begin{array}{c}\text { Specific activity } \\
(\mathrm{mg} / \mathrm{mg})+\end{array}$ & $\begin{array}{c}\text { Purification } \\
\text { (fold) }\end{array}$ \\
\hline pH 5 isoelectric precipitate & 0.53 & 95 & 0.006 & $1.85(2.20)$ \\
Post-gel filtration & $0.32(60.4)$ & 42 & 0.008 & $2.54(1.37)$ \\
Post-ion exchange & $0.28(87.5)$ & 9 & 0.031 & $10.37(4.08)$ \\
& & & &
\end{tabular}

\footnotetext{
*Values in parentheses are relative to the preceding step; +: by radioreceptor assay.
} 
A.
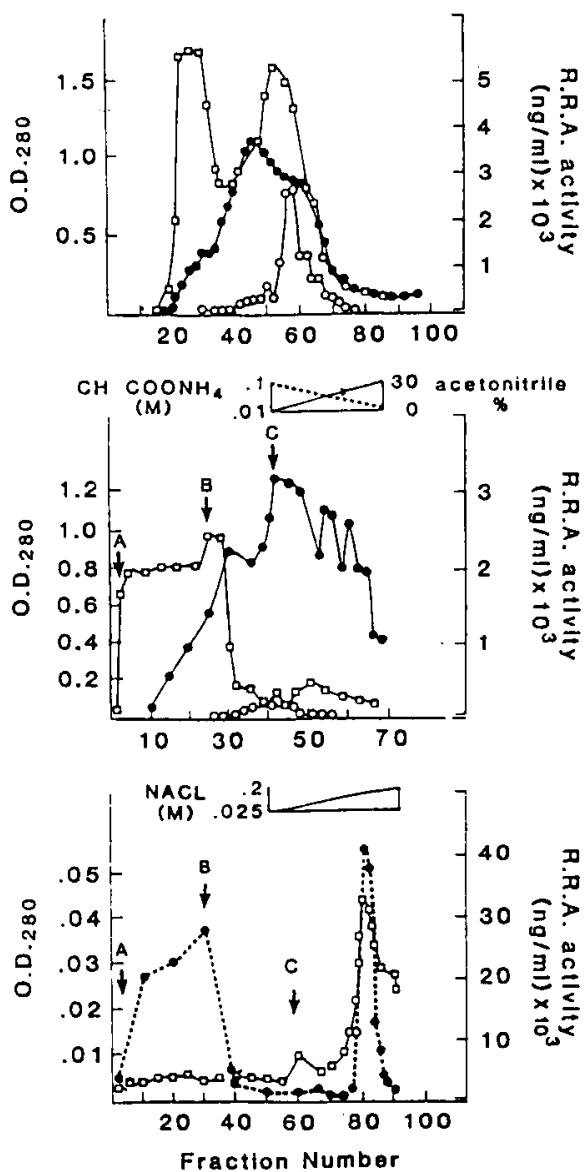

B.
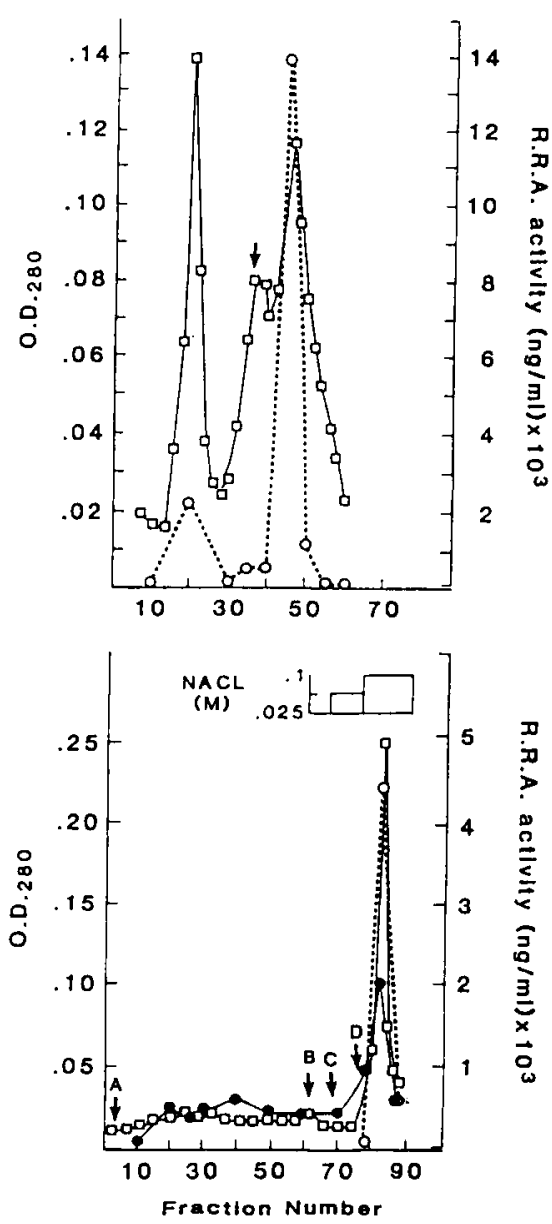

Fig 1. Purification of eGH (A) and ePRL (B). (A) Elution of crude eGH from a column of Sephadex G$100(5 \times 63 \mathrm{~cm})$ with $25 \mathrm{mM}$ ammonium acetate $\mathrm{pH} 8.5$ (top). Fractions of $15 \mathrm{ml}$ were collected at a flow rate of $1 \mathrm{ml} / \mathrm{min}$. Fractions containing eGH activity were pooled and dialyzed overnight in $100 \mathrm{mM}$ ammonium acetate, $\mathrm{pH} 8.5$ and applied to a column of phenyl Sepharose CL-4B $(1.5 \times 8 \mathrm{~cm})$ in $100 \mathrm{mM}$ ammonium acetate, $\mathrm{pH} 8.5$ (middle). Elution was achieved using a linear gradient of acetronitrile $(0-30 \% \mathrm{~V} / \mathrm{N})$ and ammonium acetate from 100 to $10 \mathrm{mM}$. Active fractions were pooled and applied to a column of DEAE-Sephacel $(1 \times 4 \mathrm{~cm})$ equilibrated with $25 \mathrm{mM}$ ammonium acetate $\mathrm{pH} 8.5$ containing $20 \%(\mathrm{VN})$ acetonitrile (bottom). After sample application at A non-adsorbed proteins were eluted with starting buffer at $B$ and adsorbed material was eluted in a gradient from 25 to $200 \mathrm{mM} \mathrm{NaCl}$ at $\mathrm{C}$. Fractions of $11 \mathrm{ml}$ were collected at a flow rate of $0.25 \mathrm{ml} / \mathrm{min}$. Equine $\mathrm{GH}$ was recovered in the breakthrough fractions and was free of ePRL (which was eluted at $100 \mathrm{mM} \mathrm{NaCl}$ in a gradient from 25-200 $\mathrm{mM} \mathrm{NaCl})(B)$ Elution of crude ePRL from a column of Sephadex G-100 (5 $\times 76 \mathrm{~cm})$ with $25 \mathrm{mM}$ ammonium acetate, $\mathrm{pH} 9.5$ (top). Fractions of $20 \mathrm{ml}$ were collected at a flow rate of $1 \mathrm{ml} / \mathrm{min}$. Fractions containing PRL were pooled and applied to a column of DEAE-Sephacel $(2.5 \times 8.5 \mathrm{~cm})$ (bottom). The column was equilibrated with starting buffer at $\mathrm{A}(25 \mathrm{mM}$ ammonium acetate, $\mathrm{pH} 8.5,15 \%$ acetonitrile) and fractions of $11 \mathrm{ml}$ were collected at a flow rate of $0.25 \mathrm{ml} / \mathrm{min}$. Non-adsorbed protein was eluted with starting buffer at $B$, followed by step-elution of ePRL with $50 \mathrm{mM} \mathrm{NaCl}$ at $C$ and $100 \mathrm{mM} \mathrm{NaCl}$ at $D$. Fractions were monitored for protein by absorbance at $280 \mathrm{~nm}(\square)$, for PRL activity by the rabbit mammary gland RRA $(\mathrm{O})$ and for GH activity in a rabbit liver RRA (๑). 
to locate, but not quantify, ePRL. The overall yield of ePRL was $10 \mathrm{mg}$ from $500 \mathrm{~g}$ of pituitary glands.

\section{Electrophoretic characterisation}

On a non-denaturing gel eGH was resolved into 3 major bands with relative mobilities $\left(R_{\mathrm{f}} \mathrm{s}\right)$ of $0.38,0.47$ and 0.58 and 1 minor band with an $R_{f}$ of 0.65 . Equine PRL was resolved into 3 major bands with $R_{\mathrm{f}}$ of 0.65 , 0.73 and 0.81 and 2 minor bands with $R_{f} s$ of 0.58 and 0.61 . Ovine PRL, which was run in parallel, was resolved into 2 major bands with $R_{\mathrm{f}} \mathrm{s}$ of 0.65 and 0.73 . (fig $2 \mathrm{~A}$ ). On a $12.5 \%$ SDS gel, eGH was resolved into 4 protein bands with molecular weights of 22500 Da for the major band and 19000 , 16500 and 15200 Da for the 3 minor components (which appeared only after several months of storage). Equine PRL migrated as 2 protein bands with a major band of $26000 \mathrm{Da}$ and a minor band of $29000 \mathrm{Da}$. Similarly oPRL was resolved into 2 protein bands of 25000 and $29000 \mathrm{Da}$ (fig 2B). Using broad range isoelectrofocusing, $\mathrm{ePRL}$ was resolved into 2 bands with isoelectric points of 5.8 and 6.2 and the 2 bands focused from eGH were 8.1 and 8.2 (data not shown).

\section{Bioactivity}

Potency estimates of eGH relative to $\mathrm{bGH}$ in the GH RRAs (using receptor sources from rabbit liver and bGH as standard and label) were high, ie 3.6 times that of bGH when pregnant rabbit liver microsomals were used (fig 3, bottom left). The eGH displacement curve was parallel to the standard $b G H$. When mare liver plasma membranes were used as the receptor source and bGH as

A.
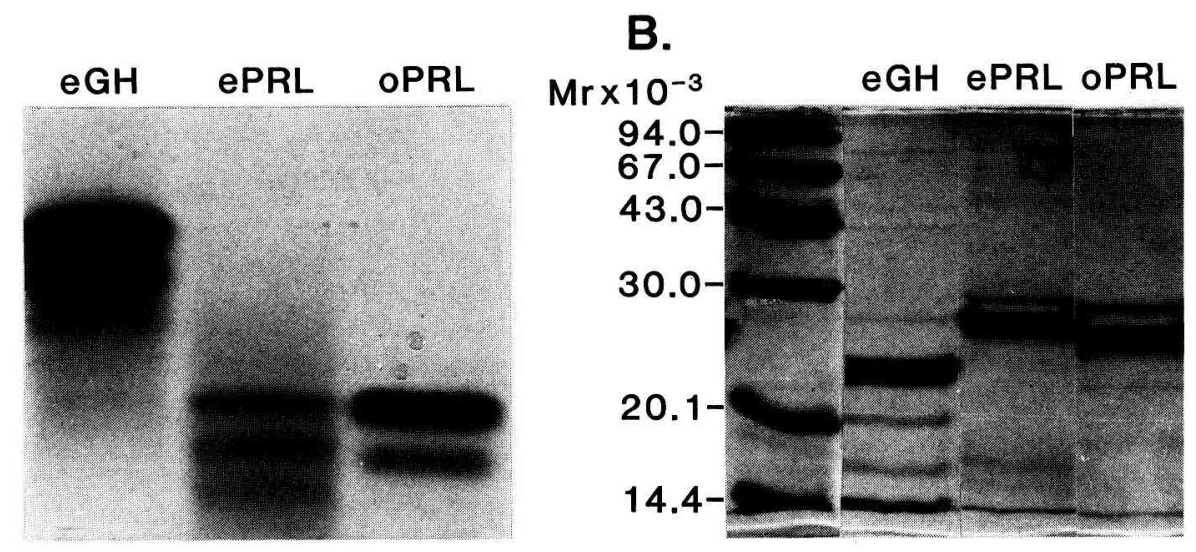

Fig 2. Analytical non-denaturing PAGE (A) of purified eGH, purified ePRL and the standard oPRL (NIAMDD oPRL-14). Alkaline discontinuous gel electrophoresis at $\mathrm{pH} 8.9$ in a $7.0 \%$ acrylamide resolving gel was carried out on $20 \mu \mathrm{g}$ of each hormone at a constant current of $20 \mathrm{~mA}$ and $180 \mathrm{~V}$ for $2 \mathrm{~h}$ on a Biorad mini-gel system. Analytical sodium dodecyl sulphate PAGE (B) of purified eGH, purified ePRL and standard oPRL (NIAMDD oPRL-14, lane 4). Electrophoresis was carried out at pH 8.8 in a $12.5 \%$ acrylamide resolving gel. Hormone samples $(20 \mu \mathrm{g})$ were prepared for electrophoresis by dissolving each in $50 \mu \mathrm{l} \mathrm{NaOH}(0.01 \mathrm{M})$ followed by addition of $0.05 \mathrm{M}$ Tris pH $6.7(50 \mu)$. The molecular weight markers were: alpha lactalbumin ( $\mathrm{Mr} 14$ 000); trypsin inhibitor ( $\mathrm{Mr} 20$ 100); carbonic anhydrase (Mr 30 000); ovalbumin (Mr 43 000); albumin (Mr 67 000); and phosphorylase B (Mr 94000$)$. 

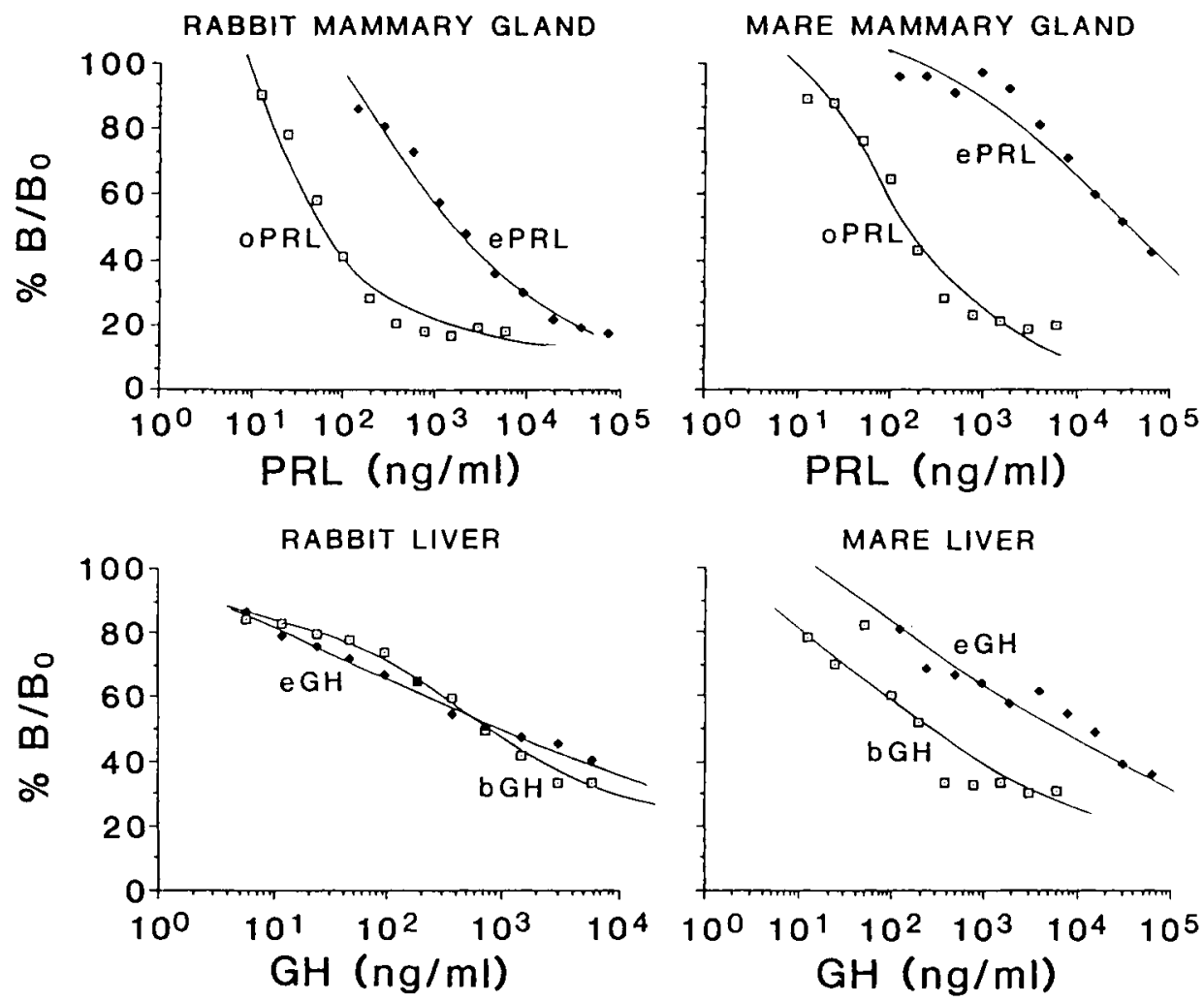

Fig 3. Characterisation of (bottom left and right) the binding of 125 -labelled bGH and unlabelled eGH to crude membranes prepared from rabbit and mare liver and the binding of 125 -labelled oPRL and radioinert $\mathrm{ePRL}$ to crude membranes prepared from rabbit and mare (top left and right) mammary tissue. Stock solutions of hormones $(2 \mu \mathrm{g} / \mathrm{ml})$ were serially diluted in assay buffer $(25 \mathrm{mM}$ Tris, $10 \mathrm{mM}$ $\mathrm{CaCl} 2,0.1 \% \mathrm{BSA}, \mathrm{pH} 7.8$ ) to give hormone concentrations in the range $0.098 \mathrm{ng}$ to $5 \mu \mathrm{g} / \mathrm{ml}$. Into plastic test tubes were added $0.1 \mathrm{ml}$ each of standard solution or sample, tracer and membrane preparation. Total binding was estimated by substituting assay buffer instead of hormone and non-specific binding estimated by using an excess $(20 \mu \mathrm{g})$ of standard. The tubes were incubated for $18 \mathrm{~h}$ at $4^{\circ} \mathrm{C}$ and the reaction was stopped by adding $2 \mathrm{ml}$ of ice-cold assay buffer followed by centrifugation at $3000 \mathrm{~g}$ for $20 \mathrm{~min}$. The supernatants were aspirated and the pellets assayed for radioactivity.

the standard and radioligand, potency estimates of $e G H$ were low $(0.045)$ relative to bGH corresponding to an activity of 0.04 $\mathrm{iu} / \mathrm{mg}$ (fig 3 , bottom right). Total binding of $125 \mathrm{I} \mathrm{bGH}$ to receptors ranged from 15.4 to $30 \%$, with non-specific binding in the range 4.8 to $11 \%$. Potency estimates of ePRL relative to oPRL, in all of the PRL RRAs (using rabbit or mare mammary gland or liver as receptor sources and oPRL as the standard and tracer) were low (0.01-0.04) corresponding to activities in the range 0.37 to $1.2 \mathrm{iu} / \mathrm{mg}$ (fig 3 , top left and right). All of the ePRL displacement curves were parallel to that of the standard, except that which used lactating rabbit mammary gland as the 
receptor source. Total binding of 125 | labelled oPRL ranged from 17 to $20 \%$, with non-specific binding in the range 4.3 to $9 \%$. In the Snell dwarf mouse bioassay, dwarf mice responded to the hormones by increased growth rates and uptake of ${ }^{35} \mathrm{SO}_{4}$ into cartilage. Both porcine and $\mathrm{eGH}$ demonstrate similar dose-response curves, with linearisation towards higher doses (40 to $160 \mu \mathrm{g}$ ) (fig 4). In the mouse mammary gland bioassay increasing doses of both equine and oPRL significantly increased the secretory grades of the cultured explants over control grades. However, the response with ePRL was significantly lower at comparable doses of lactogenic hormone. Comparison of the $E D_{50}$ values obtained from linear regression of dose-response curves gave a potency estimate of 0.4 relative to oPRL corresponding to $12.4 \mathrm{iu} / \mathrm{mg}$. In the pigeon

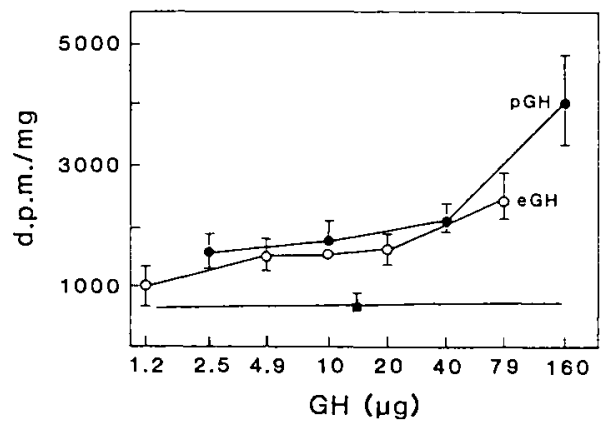

Fig 4. Dwarf mice aged 9-11 weeks and weighing between 7-10 g were randomised and allocated to different treatment groups with 6 mice per group. Hormones were injected subcutaneously into the back of individually marked animals. Weights were measured at the onset, during and after treatment. Weight gains are expressed relative to whole body starting weight. On day $1 \mathrm{pGH}(2.5,10,40$ and $160 \mu \mathrm{g}$ per 0.1 $\mathrm{ml})$ and $\mathrm{eGH}(1.2,4.8,19.2$ and $76.8 \mu \mathrm{g}$ per 0.1 $\mathrm{ml}$ ) were injected, making 9 treatment groups (including a saline control). On day 2 , a second hormone injection was given by the same route and on day 3 mice were given a dose of ${ }^{35} \mathrm{SO}_{4}^{2-}$ relative to body weight $(0.5 \mu \mathrm{Ci} / \mu \mathrm{g})$ ip and killed $20 \mathrm{~h}$ later. Uptake of $35 \mathrm{SO}_{4}^{2-}$ into costal cartilage was measured as described by Holder et al (1980). crop sac bioassay ePRL gave a potency estimate of $29.23 \mathrm{iu} / \mathrm{mg}(15.8-53.6 \mathrm{iu} / \mathrm{mg})$.

\section{Immunoactivity}

Equine $\mathrm{GH}$ cross-reacted fully in the $\mathrm{pGH}$ RIA of Buttle (1987a) and parallel dose-response curves were obtained (fig $5 A)$. The potency of ePRL relative to $P P R L$ in a homologous PPRL RIA was 0.96 (32.6 $\mathrm{iu} / \mathrm{mg}$ ) (fig 5B). Equine PRL cross-reacted fully in the homologous ePRL RIA of Worthy et al (1986).

\section{Radioimmunoasay of eGH}

A dose-response curve for eGH in the $\mathrm{eGH}$ RIA is presented in fig 6A. The limit of sensitivity of the assay, defined as the concentration of hormone which gave a $\mathrm{B} / \mathrm{B}_{0}$ ratio of $90 \%$ was $1.2 \mathrm{ng} / \mathrm{ml}$ (where $B$ is specific binding and $B_{0}$ is total binding). Ovine, bovine and human $\mathrm{GH}$ at concentrations of up to $800 \mathrm{ng}$ per tube showed no significant displacement of $125 \mathrm{I}$ eGH, only pGH showed inhibition with a cross-reactivity of $0.24 \%$ (fig 6A) however the slope of the dose-response curve was non-parallel to the eGH standard. Of the PRLs tested, ovine, bovine, rat, porcine and equine, at concentrations up to $400 \mathrm{ng}$ per tube, none showed any significant displacement; only ePRL showed inhibition with a slight crossreactivity of $0.9 \%$. The equine gonadotropin fraction did not cross-react in the assay: Dose-response curves of a crude pituitary gland extract and plasma samples collected from a mare and foal are also shown and dose-response curve analysis revealed that all curves were parallel. The quantitative recovery of eGH standard, serial dilutions from 2.5 to $20 \mathrm{ng} / \mathrm{ml}$, added to equine plasma was $86.2 \pm 3.3$ (se)\% with a mean intra- and interassay CV of 6.0 and $9.9 \%$, respectively $(n=6)$ for repeated determinations on plasma pools. 

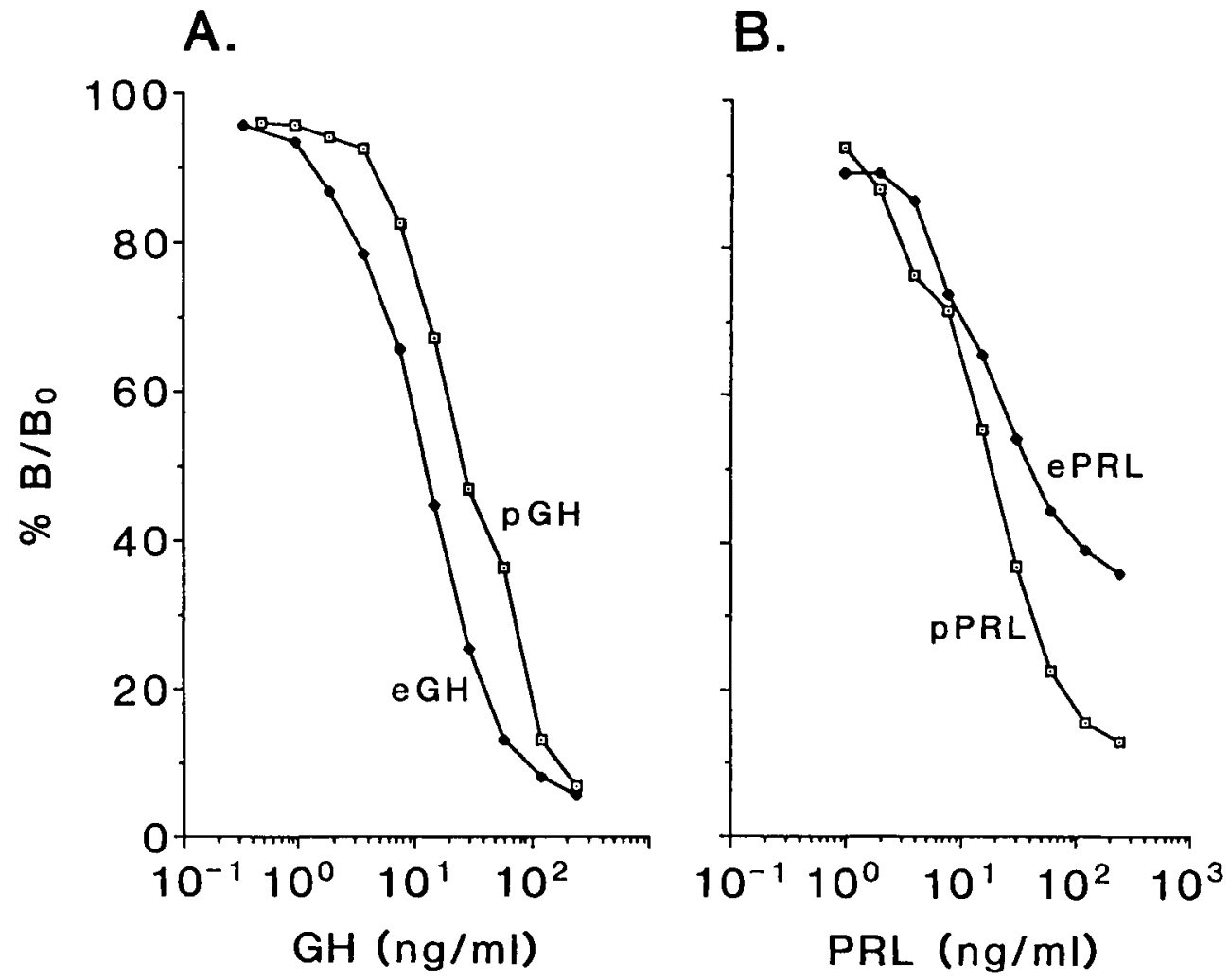

Fig 5. Dose-response curves for (A) eGH in a homologous porcine GH RIA and (B) ePRL in a homotogous porcine PRL RIA. Assays were performed as described by Buttle (1987b). In A, guinea-pig anti-pGH, $0.1 \mathrm{ml}$ (batch 1/2,1:20 000) was added to $0.2 \mathrm{ml}$ of sample or standard $(0.8-200 \mathrm{ng} / \mathrm{ml}), 0.2$ $\mathrm{ml}$ hypophysectomised goat plasma, $0.1 \mathrm{ml}$ of normal guinea-pig serum and $0.1 \mathrm{ml}$ of 125$) \mathrm{pGH}$ (10 000 $\mathrm{cpm})$. After overnight incubation $0.1 \mathrm{ml}$ of goat anti-guinea-pig IgG $(1: 100)$ was added and was incubated for a further $18 \mathrm{~h}$. In B, anti-pPRL $(0.1 \mathrm{ml}$, guinea-pig B3/2, 1:20 000) was added to sample or standard pPRL $(0.8-200 \mathrm{ng} / \mathrm{ml}, 0.2 \mathrm{ml})$ and hypophysectomised goat plasma $(0.2 \mathrm{ml}), 0.1 \mathrm{ml}$ normal guinea-pig serum (1:200) and $0.1 \mathrm{ml}{ }^{125} \mathrm{pPRL}(13000 \mathrm{cpm})$. Following overnight incubation at $4^{\circ} \mathrm{C}$, $0.1 \mathrm{ml}$ of goat anti-guinea-pig IgG (1:50) (Batch GA 2448F; Cambridge Medical Diagnostics) was added and incubated as described above. Assays were stopped by standard procedures.

\section{Radioimmunoassay of ePRL}

A dose-response curve for ePRL in the RIA is presented in figure $6 \mathrm{~B}$. The limit of sensitivity of the assay was $0.5 \mathrm{ng} / \mathrm{ml}$. Of the PRLs tested (ovine, bovine and rat) at concentrations of up to $800 \mathrm{ng}$ per tube, none showed any significant displacement. Only
pPRL showed inhibition with a slight crossreactivity of $0.4 \%$. Ovine, bovine or $\mathrm{pGH}$ at concentrations of up to $800 \mathrm{ng}$ per tube showed no significant displacement of 125| ePRL. Only eGH showed slight inhibition with a cross-reactivity of $0.1 \%$. The effect of different dilutions of crude alkaline extract of equine pituitary gland and of plasma samples collected from a mare and a foal are 


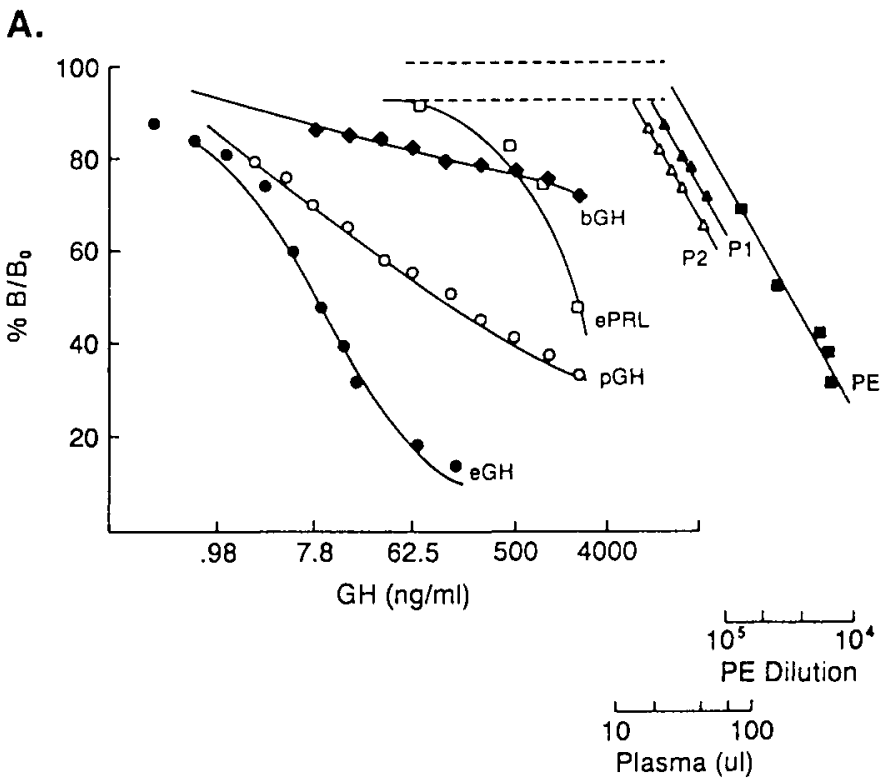

B.

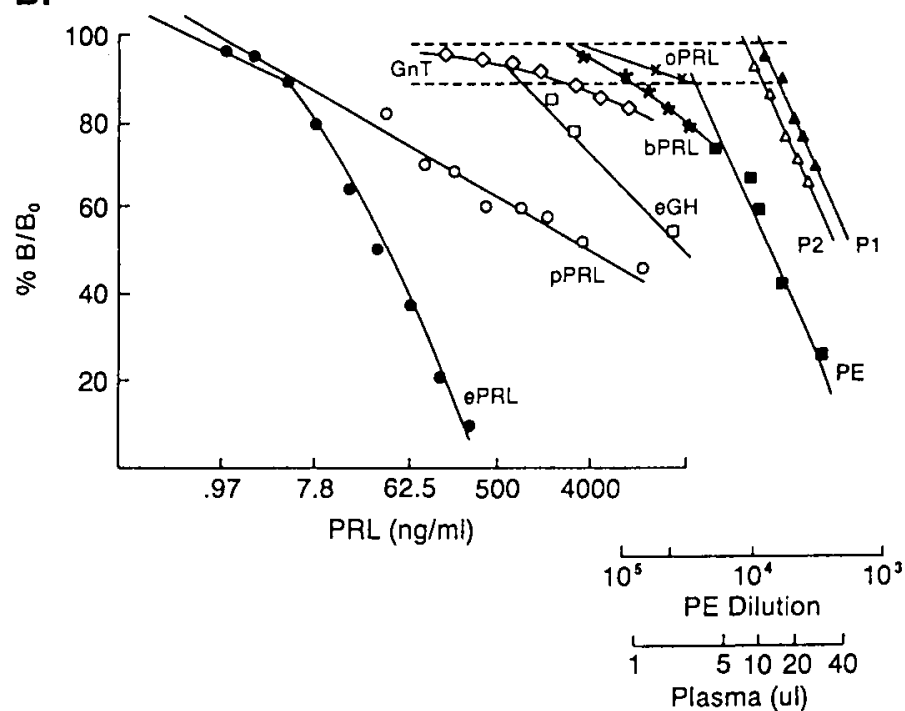

Fig 6. Dose-response curves of different hormone preparations in the homologous eGH RIA (A) and in the homologous ePRL RIA (B). In A, the preparations used were porcine GH (USDA-B1), bovine GH (NIH-B18) and purified equine PRL. The results for ovine PRL (NIH-P-S12), bovine PRL, (NIAMDDbPRL-6), rat PRL (NIDDK B-6), porcine PRL (USDA B-1), ovine GH (NIH S-11), and human GH (MRC) are contained within the broken lines. In $B$, the preparations used were porcine PRL (USDA B1), ovine PRL (NIH-P-S12), bovine PRL (NIAMMD bPRL-6) and purified equine GH. The results for ovine GH (NIH-S-11), bovne GH (NIH-b18), porcine GH (USDA-B-1) and rat PRL (NIDDK-rPRL-B-6) were contained within the broken lines. PE (an alkaline extract of equine pituitary gland), GnT (an equine gonadotrophin fraction) and P1 and P2 (dilutions of plasma samples from a mare and a foal respectively). 
presented and dose-response curve analysis revealed that all curves were parallel. Recovery of ePRL standard (serial dilutions from 2.5 to $20 \mathrm{ng} / \mathrm{ml}$ ) added to equine plasma was $111 \pm 5.36$ (se)\% with a mean intra- and interassay CV of 9.1 and $15.6 \%$, respectively $(n=6)$.

\section{Effect of administration of TRH on plasma PRL and GH}

Two out of the $3 \mathrm{TRH}$ injected animals responded with a rapid surge of PRL within $15 \mathrm{~min}$. The vehicle injected lactating mare, as expected, did not exhibit any increase in PRL (fig 7A). PRL concentrations in the nonlactating mare were highest 45 min postinjection reaching $10.9 \mathrm{ng} / \mathrm{ml}$ and declined thereafter to $4.9 \mathrm{ng} / \mathrm{ml} 150 \mathrm{~min}$ post-injection. PRL secretion in the stallion was elevated to an even greater extent $(22.8 \mathrm{ng} / \mathrm{ml})$ with the time course of the effect approximating to that of the non-lactating mare. The TRH injected lactating mare failed to respond as rapidly as the others, but exhibited a rise in PRL from 2 to $7 \mathrm{ng} / \mathrm{ml}$ between 120 and 150 min post injection. This mare had also experienced a natural pulse of $P R L$ just before TRH injection. In all of the TRH injected animals there was no immediate rise in $\mathrm{GH}$. In the non-lactating mare concentrations ranged from 4 to $8 \mathrm{ng} / \mathrm{ml}$, in the stallion from 2.5 to $8 \mathrm{ng} / \mathrm{ml}$ and in the lactating mare from 1 to $3.5 \mathrm{ng} / \mathrm{ml}$. The vehicleinjected lactating mare had concentrations in the range 2 to $10 \mathrm{ng} / \mathrm{ml}$ and exhibited a large pulse of $\mathrm{GH} 30$ to 120 min post-vehicle injection (fig 7B).

\section{Administration of $h G R F_{(1-29)}$ and the effect of fasting on plasma $G H$}

Overall mean GH concentrations did not differ significantly in the saline or GRF-treated animals over the sampling period with con- centrations of $3.83 \pm 0.31$ (se) $\mathrm{ng} / \mathrm{ml}(n=$ 3) for the saline group and $5.32 \pm 1.18$ (se) $\mathrm{ng} / \mathrm{ml}(n=3)$ for the hGRF $(1-29)$-treated group. Both groups exhibited a pulse of $\mathrm{GH}$ after infusion at $12.00 \mathrm{~h}$ and although the $\mathrm{GH}$ pulse in the GRF-treated group appeared earlier (5 min post-infusion, $c f, 15$ min for the saline treated) the timing was not significant (fig 8). Similarly fed and fasted horses had concentrations of $\mathrm{GH}$ which did not differ significantly $(3.81 \pm 0.96(\mathrm{se}) \mathrm{ng} / \mathrm{ml}$ $(n=6)$ (fed) and $4.5 \pm 0.79$ (se) $\mathrm{ng} / \mathrm{ml}(n=$ 6) (fasted) over the time period examined.

\section{GH and PRL secretory profiles}

The profiles are characterized by large intermittent elevations in $\mathrm{GH}$ concentrations separated by trough periods during which $\mathrm{GH}$ returns to basal levels (fig 9A). In mare \#101 concentrations of $\mathrm{GH}$ ranged from 1.8 to $29.08 \mathrm{ng} / \mathrm{ml}$ with up to 7 -fold changes detected in a time period of $1 \mathrm{~h}$. Mean 24-h $\mathrm{GH}$ were $5.3,6.4$ and $5.5 \mathrm{ng} / \mathrm{ml}$ in weeks 1,3 and 6 of lactation. In mare \#102 GH concentrations ranged from 1.7 to 89.6 $\mathrm{ng} / \mathrm{ml}$ with up to 23 -fold changes in $\mathrm{GH}$ detected in a time period of $1 \mathrm{~h}$. Mean 24- $\mathrm{h}$ $\mathrm{GH}$ concentrations were 6.26 and 7.14 $\mathrm{ng} / \mathrm{ml}$ in weeks 1 and 8 respectively. In the non-lactating mare \#104 the overall 24-h mean $\mathrm{GH}$ was $5.9 \mathrm{ng} / \mathrm{ml}$ and in the stallion $\# 105,7.3 \mathrm{ng} / \mathrm{ml}$ with no distinct elevations in hormone concentration (profile not shown).

Lactating mare PRL profiles are characterized by long discrete episodic bursts, defined by increasing PRL concentrations due to more or less superimposed or partially overlapping secretory pulses. These are separated by relatively quiescent periods when PRL concentrations returned to basal levels. In mare \#101 concentrations ranged from 1 to $23 \mathrm{ng} / \mathrm{ml}$ with up to 5 -fold changes detected in $75 \mathrm{~min}$. Mean $24 \mathrm{~h}$ PRL concentrations decreased from 5.27 to 4.18 $\mathrm{ng} / \mathrm{ml}$ from week 1 to week 6 of lactation. 

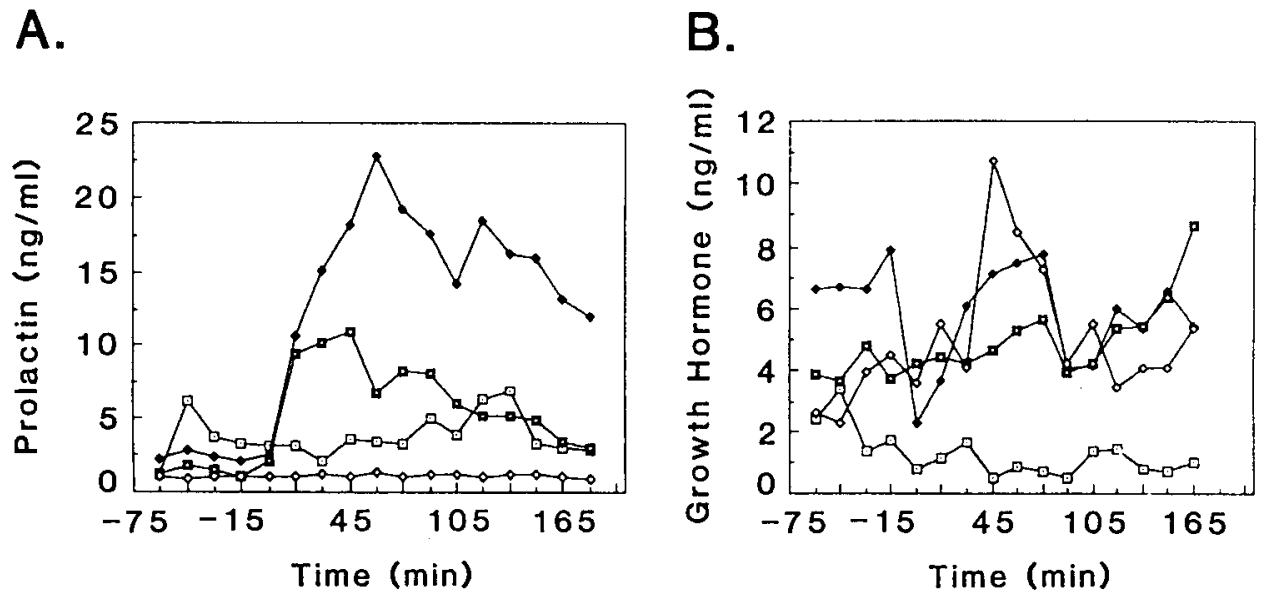

Fig 7. Plasma PRL (A) and $\mathrm{GH}(\mathrm{B})$ in response to an intravenous injection of $2.34 \mathrm{mg} T R H$ in a lactating mare $(\square)$, a non-lactating mare $(\square)$ a stallion $(\bullet)$ and an injection of physiological saline in a lactating mare $(0)$. Blood samples were collected at $15 \mathrm{~min}$ intervals from -60 to $180 \mathrm{~min}$ relative to injection.
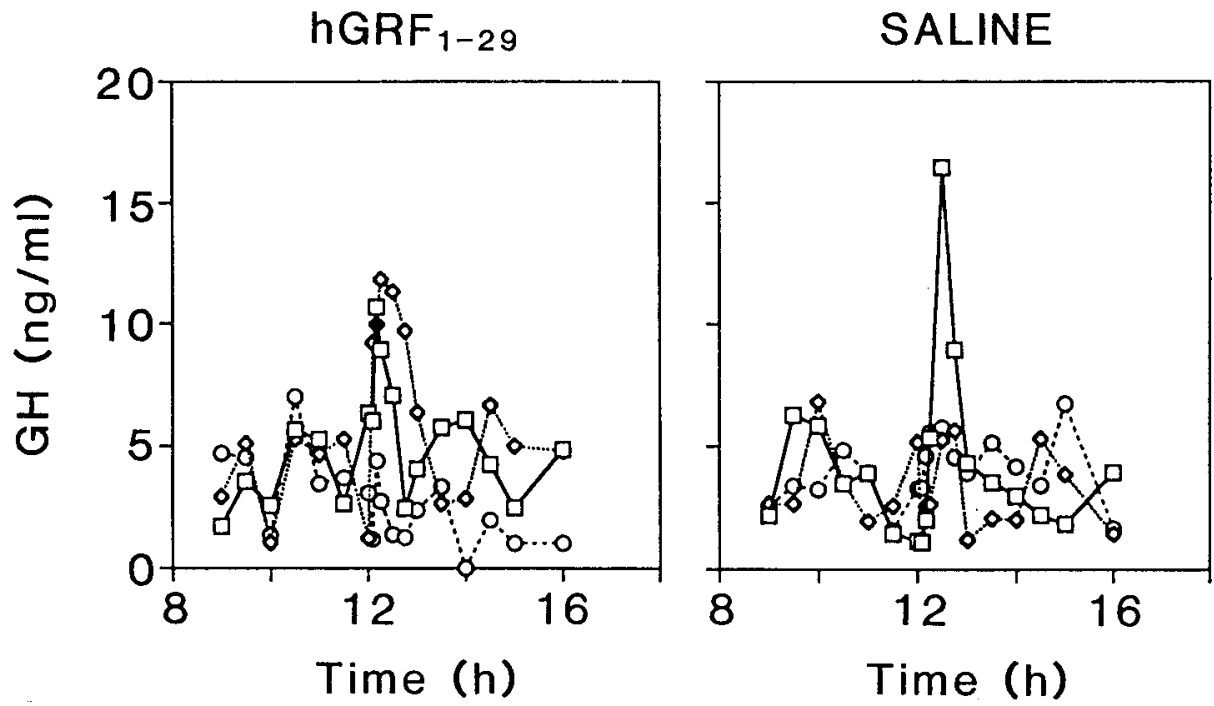

Fig 8. Plasma GH in response to an intravenous injection of $670 \mu \mathrm{g}$ of $\mathrm{hGH}_{(1-29)}$ or saline administered to 3 Dutch warm-blooded mares. Blood samples were collected at $-180,-150,-120,-90,-60,-30$, $0,5,10,15,30,45,60,90,120,150,180$ and 240 min relative to the administration of $h G F_{(1-29)}$ at noon. 


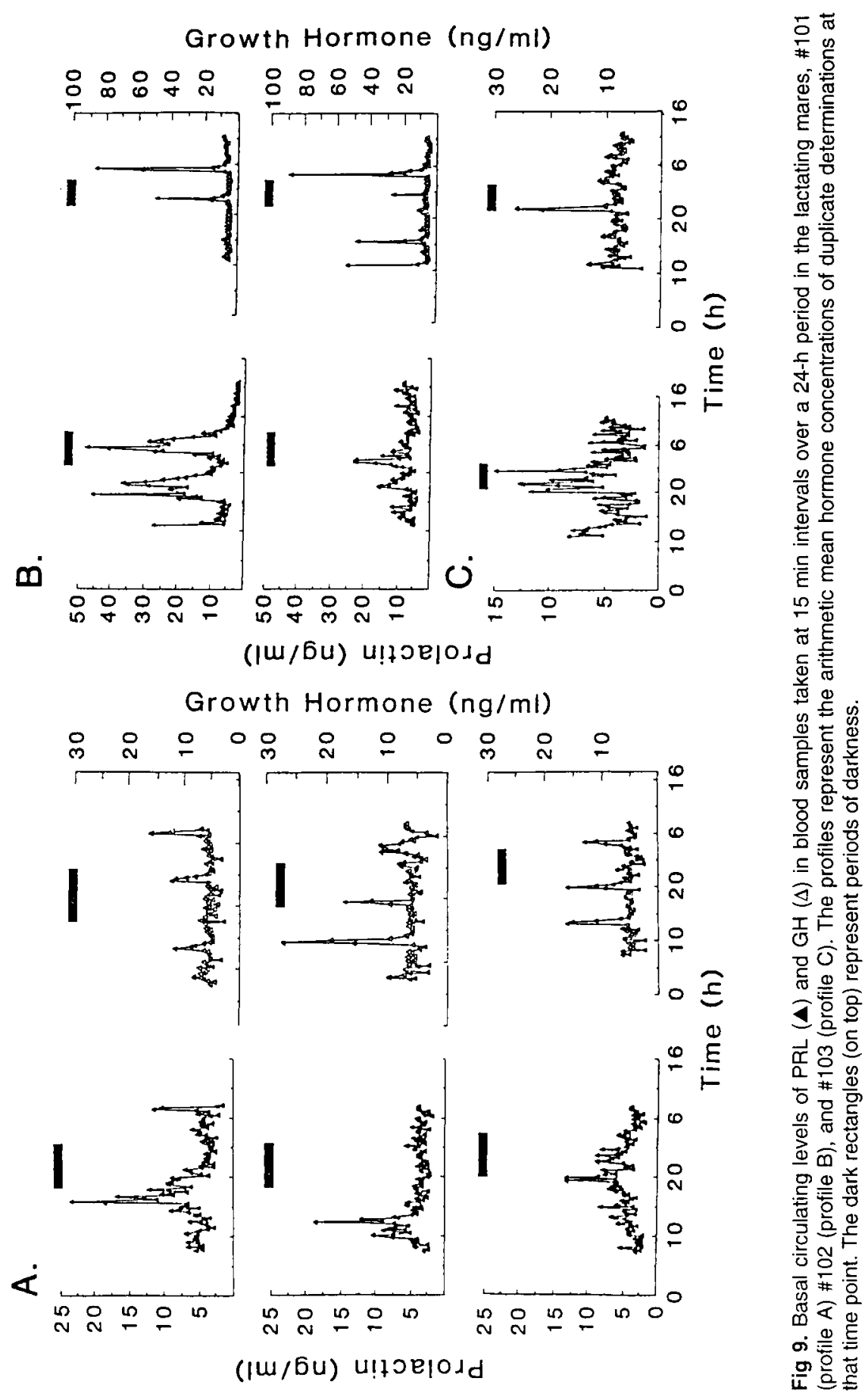


In mare \#102 PRL concentrations ranged from 1 to $46 \mathrm{ng} / \mathrm{ml}$ with up to 9-fold changes detected in $75 \mathrm{~min}$. Mean $24 \mathrm{~h}$ PRL decreased from 10.89 to $6.48 \mathrm{ng} / \mathrm{ml}$ from weeks 1 to 8 of lactation. Two episodic bursts were detected in this mare with both light and dark peaks indicating the presence of a biphasic secretory pattern (fig 9). No major elevations in PRL could be detected in \#104, the non-lactating mare or in \#105 the stallion 24-h PRL profiles; the overall 24-h mean PRL concentrations were 3.18 and $3.29 \mathrm{ng} / \mathrm{ml}$ respectively.

\section{DISCUSSION}

Highly sensitive, specific RIAs for eGH and ePRL have been developed employing highly purified and well-characterised preparations of hormone. These assays have been employed in the assay of closely timed plasma samples over $24 \mathrm{~h}$ in both lactating and non-lactating animals. Specific patterns of secretion for each hormone were described.

To our knowledge, this is the first report of a homologous RIA for eGH. Previous studies have relied on heterologous assays, employing antiserum to $\mathrm{pGH}$ and $\mathrm{pGH}$ as the label (Thompson et al, 1992). The validation data presented here show that the sensitivity, precision and accuracy of the RIA is adequate for the investigation of changes in GH concentrations. Cross-reactivity studies of purified preparations of several mammalian GHs and PRLs as well as equine gonadotrophins in the RIA have demonstrated that the assay was highly specific for eGH. In the case of ePRL, its crossreactivity was low suggesting very little cross-contamination with eGH. Since the primary structure and function of $\mathrm{GH}$ and PRL are similar in some mammalian species (Bewley et al, 1972) it was important that the cross-contamination was low for validation of both the eGH and ePRL assays. In addition, the ability to detect added $\mathrm{GH}$ to plasma samples, and the parallelism of plasma GH and crude pituitary extracts are consistent with the assay being capable of quantifying $\mathrm{GH}$ without interference.

The ePRL RIA developed here is the second reported homologous RIA for equine $P R L$, all other assays being heterologous RIAs (Thompson et al, 1986a; Lothrop et al, 1987). The performance characteristics of the equine PRL RIA described here are at least as good as those of the other RIAs for ePRL. Cross-reaction studies with purified preparations of several mammalian PRLs and $\mathrm{GHs}$ as well as equine gonadotrophins showed that the assay was highly specific for ePRL. In the case of eGH, its cross-reactivity in the ePRL RIA was low (0.12\%) suggesting very little cross-contamination of the ePRL standard with eGH. No interference by plasma components was observed in the RIA as demonstrated by the parallelism of the inhibition curves of plasma PRL and crude PRL pituitary extracts, and the good recoveries of exogenous ePRL added to plasma samples.

Similar yields and size estimates for $\mathrm{eGH}$ have been obtained by previous investigators (Saxena and Henneman, 1966; Hartree et al, 1968; Conde et al, 1973). Equine GH showed full cross-reactivity in the bGH RRA employing rabbit liver and labelled bGH but had a low potency when the receptor preparation was from mare liver with the same label. We were unable to demonstrate specific binding of labelled eGH to either mare or rabbit liver receptors. Equine GH was equipotent with $\mathrm{pGH}$ in the Snell dwarf mouse bioassay and in a homologous porcine $\mathrm{GH}$ RIA confirming the purity of eGH and its immunological identity with porcine $\mathrm{GH}$.

Similar to the binding pattern seen with $\mathrm{eGH}$ and bGH in mare liver (ie higher affinity of bGH), although ePRL could bind to mare and rabbit mammary gland and liver, it competed much less effectively than oPRL. This is similar to the results of Jerry 
et al (1991) who found that specific binding of oPRL to porcine mammary membranes was greater than specific binding of the homologous $\mathrm{pPRL}$. It is possible that oPRL binds to sites in the equine mammary gland in addition to the authentic lactogenic receptor or that it has a higher affinity for the equine lactogenic receptor. It has been suggested that homologous PRLs are unstable and may be uniquely cleaved at the plasma membrane and released as 16 and $8 \mathrm{kDa}$ fragments (Clapp, 1987). It is also possible that chemical damage to ePRL, but not oPRL, during iodination could explain this discrepancy in binding. Parke and Forsyth (1975) have also demonstrated that preparations of canine and ePRL with high pigeon crop sac stimulating activity, were less than $1 \mathrm{iu} / \mathrm{mg}$ in terms of the ovine PRL standard in the rabbit liver RRA. The high potency of ePRL in the pigeon crop sac bioassay compares well to the values obtained by other investigators (Chen et al, 1979; Li and Chung, 1983) and its low potency in the mouse mammary gland bioassay emphasizes the need to examine the action of hormones using homologous systems. The purity of our ePRL standard was confirmed in a previously established homologous ePRL RIA (Worthy et al, 1986) and significant cross-reactivity was obtained with a homologous porcine PRL RIA, which conforms well with the close structural homology between these hormones (Lehrman et al, 1988).

The lack of response of plasma $\mathrm{GH}$ to hGRF $F_{(1-29)}$ was somewhat surprising, but it is known that several factors can affect an animal's ability to respond. Dubreuil et al (1987) found that the GH response to GRF in the swine was affected by age, sex and the timing of the GRF infusion relative to a natural pulse of $\mathrm{GH}$ with females responding better than males. Thompson et al (1992) have reported a response to porcine GRF in 8 out of 9 mares administered the hormone. The results of the TRH stimula- tion test showed that it is unlikey that the horse responds to this hormone by rising plasma $\mathrm{GH}$, confirming the results of Thompson et al (1992). However elevations in PRL concentrations after TRH administration were detected, supporting the observations of previous investigators (Thompson and Nett, 1984; Thompson et al, 1986a; Johnson, 1987). The results also suggest that the PRL response to TRH in the mare may become refractory as in the lactating mare a large peak of PRL was detected prior to $\mathrm{TRH}$ injection and the rise in PRL post-TRH administration was not observed until $1 \mathrm{~h}$ afterwards.

Peak lactation in the mare occurs at around 8 weeks and weaning in natural herds occurs 35-40 weeks after birth (Duncan et al, 1984). The 24-h profiles shown are from mares in early to peak lactation. Closely timed blood samples over 24-h periods showed 2 quite distinct patterns of secretion for $\mathrm{PRL}$ and $\mathrm{GH}$ in the lactating mare. Large 'unimodal pulses' of $\mathrm{GH}$ and 'episodic bursts' of PRL were the typical patterns of secretion in the lactating mare. The pattern of secretion of $\mathrm{GH}$ is similar to that described in lactating pigs and cows (Buttle, 1987a; Bines et al, 1983). In lactating cows, no consistent pattern of $\mathrm{GH}$ secretion was found at any stage of lactation but very high short-lived peaks of $\mathrm{GH}$ occurred at irregular intervals in high yielding cows at peak lactation. In the dry period and in low yielding cows these peaks were smaller and less frequent, compared with the smaller $\mathrm{GH}$ elevations observed in the non-lactating mare. Buttle (1987a) has ascribed the pattern of $\mathrm{GH}$ secretion in lactating pigs to weight loss and negative energy balance. It is noteworthy that many of the $\mathrm{GH}$ pulses recorded in the mare coincided with the onset or occurred during the dark period. In man the onset of typical slow-wave sleep stimulates an increase in the blood level of GH (Honda et al, 1969) and this release is inhibited by the occurrence of paradoxical sleep. 
No consistent pattern of PRL secretion was detected between all the mares but each mare had her own characteristic pattern. In mare \#101 one episodic burst occurred in the afternoon. Roser et al (1987) have also shown evidence of a midday diurnal surge in PRL in mares. In mare \#102 a biphasic pattern was observed with both light and dark peaks. Similarly Lincoln (1979) observed both a day- and a night-time peak of PRL in the ram, and a similar diurnal rhythm has been reported with a nadir around noon and a peak before midnight in the ewe (Wallace et al, 1988). The 3 lactating mares were freely lactating, ie foals remained with the mares, and all animals were fed ad libitum ensuring undisturbed patterns of hormone secretion. When Wiest and Thompson (1987) separated dams from foals and reunited them some time later they found that PRL was released in some but not all mares. However the continuous suckling pattern throughout certain time intervals typical of the foal may result in the release of relatively small quantities of the hormone throughout the period of stimulation, as occurs in the lactating rat (Grosvenor and Whitworth, 1974) making elevations in hormone concentrations due to the effects of suckling difficult to observe. Moreover, when suckling episodes occur frequently there is insufficient time between them for PRL levels to fall to low levels and so basal concentrations of PRL remain elevated.

In conclusion, we have developed new homologous RIAs for eGH and ePRL using highly purified and well-characterised preparations of hormones. The RIA for $\mathrm{eGH}$ has enabled initial studies of the physiology of $\mathrm{eGH}$ and it will enable us to carry out more extensive studies to define more clearly the physiological role of $\mathrm{eGH}$ in the horse.

\section{ACKNOWLEDGMENTS}

We wish to thank the Faculty of Veterinary Medicine and the Faculty of Agriculture, Univer- sity College Dublin for access to the horses, $P$ Brophy for insertion of cannulae and $N$ Kean for help with the blood sampling. We gratefully acknowledge the collaboration of $J$ Gosling, Dept of Biochemistry, University College Galway, $\mathrm{H}$ Buttle, AFRC, IGAP, Hurley, Maidenhead, Berks UK, and I Forsyth and A Holder, AFRC, Babraham, Cambridge UK.

\section{REFERENCES}

Abdul-Ahad WJ (1984) Six non-isotopic assays for bovine LH. PhD thesis, National University of Ireland

Bewley TA, Dixon JS, Li CH (1972) Sequence comparison of human pituitary growth hormone, human chorionic somatomammotropin and ovine pituitary growth hormone and lactogenic hormones. Int $J$ Pep Protein Res 4, 281-287

Bines JA, Hart IC, Morant SV (1983) Endocrine control of energy metabolism in the cow. Diurnal variations in the concentration of hormones and metabolites in the blood plasma of beef and dairy cows. Horm Metab Res 15, 330-334

Buttle HL (1987a) Changes in the pattern of growth hormone episodic secretion during late pregnancy and lactation in sows. J Endocrinol 115, 167

Buttle HL (1987b) Some effects of total mastectomy upon subsequent reproductive performance in sows. Br Vet J 143, 318-327

Chen CL, Neilson JTM, Kumar MSA, Estes MS (1979) Isolation and partial characterisation of prolactin from equine pituitary gland (hypophysis). Am J Vet Res 40 , 1303-1306

Clapp C (1987) Analysis of the proteolytic cleavage of prolactin by the mammary gland and liver of the rat. Characterisation of the cleaved and $16 \mathrm{~K}$ forms. Endocrinology 121, 2055-2064

Conde RP, Paladini AC, Santome JA, Dellacha JM (1973) Isolation, purification and characterisation of equine growth hormone. Eur Biochem 32, 563-568

Davis BJ (1964) Disc electrophoresis 11. Method and application to human serum proteins. Ann New York Acad Sci 121, 404-427

De Lean A, Munson PJ, Rodbard D (1978) Simultaneous analysis of families of sigmoid curves, application to bioassay, radioligand assay and physiological dose-response curves. Am J Physiol 235, E97-E102

Dubreuil P, Pelletier G, Petit-clerc et al (1987) Influence of age and sex on basal secretion of $\mathrm{GH}$ and on $\mathrm{GH}$ induced release by porcine $\mathrm{GH}$ releasing factor pGRF (1-29 NH2) in growing pigs. Domest Anim Endocrino/ 4/4 299-307

Duncan P, Harvey PH, Wells SM (1984) On lactation and associated behaviour in a natural herd of horses. Anim Behav 32, 255-263 
Farmer SW, Papkoff H, Licht P (1975) Purification of turkey gonadotrophins. Biol Reprod 12, 145-422

Finney DJ (1978) Statistical Method in Biological Assay. 2nd ed, Charles Griffin and Co, Ltd, London

Gill JC (1986) Repeated measurement: sensitive tests for experiments with few animals. J Anim Sci 63,943 954

Grosvenor CE, Whitworth N (1974) Evidence for a steady state of secretion of prolactin following suckling in the rat. J Dairy Sci 57, 900-904

Hartree AS, Mills JB, Welch RAS, Thomas M (1968) Fractionation of protein hormones from horse pituitary glands. J Reprod Fertil 17, 291-303

Hayden TJ, Brennan D, Quirke K, Murphy P (1991) $X a n t h i n e$ oxidase/dehydrogenase in mammary gland of mouse: relationship to mammogenesis and lactogenesis in vivo and in vitro. J Dairy Res 58, 401409

Holder A, Wallis M, Biggs MP, Preece MA (1980) Effect of growth hormone, prolactin and thyroxine on body weight, somatomedin-like activity and in vivo sulphation of cartilage in hypopituitary dwart mice. $J$ Endocrinol 85, 35-47

Honda $Y$, Takahashi $K_{+}$Takahashi S et al(1969) Growth hormone secretion during nocturnal sleep in normal subjects. J Clin Endocinrol Metab 29, 20-29

Jerry DJ, Griel LC, Kavanaugh JF, Kensinger RS (1991) Binding and bioactivity of ovine and porcine prolactins in porcine mammary tissue. J Endocrinol 130 , 43.51

Johnson AL (1986) Serum concentrations of prolactin, thyroxine and triiodothyronine relative to season and the estrus cycle in the mare. J Anim Sci62, 10121020

Johnson AL (1987) Seasonal and photoperiod induced changes in serum prolactin and pituitary responsiveness to thyrotropin-releasing hormone in the mare (42455). Proc Soc Exp Biol Med 184, 118122

Laemmli UK (1970) Cleavage of structural proteins during the assembly of the head of Bacteriophage T4. Nature (Lond) 227, 681-685

Lehrman SW, Lahm HW, Miepel MC, Hulmes JD, Li CH (1988) Primary structure of equine pituitary prolactin. Int J Pept Protein Res 34, 544-554

$\mathrm{LiCH}, \mathrm{Chung} D$ (1983) Studies on prolactin 48: isolation and properties of the hormone from horse pituitary glands. Arch Biochem Biophys 220, 208-213

Licht P, Papkoff H, Farmer SW, Muller $\mathrm{CH}$, Wotsui $\mathrm{H}$, Crews D (1977) Evolution of gonadotrophin structure and function. Recent Prog Hom Res 33, 169-248

Lincoln GA (1979) Light-induced rhythms of PRL secretion in the ram and the effect of cranial sympathectomy. Acta Endocrinol 91, 421-427

Lothrop CD, Henton JA, Cole BB, Nolan HL (1987) Prolactin response to thyrotropin-releasing hormone stimulation in normal and agalactic mares. $J$ Reprod Fertil 35 (suppl), 277-280

Morrison DF (1967) Multivariate Statistical Methods. MC Graw-Hill, New York

Nicoll CS (1967) Bioassay of prolactin. Analysis of the pigeon crop sac response to local prolactin injection by an objective and quantitative method. Endocrinology 80, 641-655

Parke L, Forsyth IA (1975) Assay of lactogenic hormones using receptors isolated from rabbit liver. Endocr Res Commun 2, 137-149

Poskus E, Zakin MM, Femandez HN, Paladini AC (1976) Detection of immunologically active zones in equine growth hormone. Eur J Immunol 6, 409-417

Roser JF, Chang YS, Papkoff $\mathrm{H}, \mathrm{Li} \mathrm{CH}$ (1984) Development and characterisation of a homologous radioimmunoassay for equine prolactin. Proc SoC Exp Biol Med 175, 510-517

Roser JF, O'Sullivan J, Evans JW, Swedlow J, Papkoff $H(1987)$ Episodic release of prolactin in the cycling mare. J Reprod Fertil 27 (suppl), 687-688

Rosner B (1990) Fundamentals of Biostatistics. PWSKent Publishing Company, Boston, USA

Salacinski PR, Mc Clean C, Sykes JE, Clement-Jones VV, Lowry PJ (1981) lodination of proteins, glycoproteins and peptides using a solid phase oxidizing agent, 1,3,4,6 tetrachloro-3,6-diphenylglycouril (iodogen). Anal Biochem 117, 136-146

Saxena BB, Henneman PH (1966) Preparation and properties of growth hormone from equine pituitary glands. Endocrinology 78, 561-567

Shiu RCP, Kelly PA, Friesen HG (1973) Radioreceptor assay for prolactin and other lactogenic hormones. Science 180, 967-971

Thompson DL, Nett TM (1984) Thyroid-stimulating hormone and prolactin secretion after thyrotrophin-releasing hormone administration to mares, dose-response during anestrus in winter and during estrus in summer. Domest Anim Endocrinol 13, 263-268

Thompson DL, James JR, Wiest JJ, Nett TM (1986a) Measurement of equine prolactin with an equinecanine radioimmunoassay, seasonal effects on the prolactin response to thyrotropin releasing hormone. Domest Anim Endocrinol 3, 247-252

Thompson JN, Caudle AB, Kempainnen RJ, Nett TM, Brown J, Williams DJ (1986b) Thyroidal and prolactin secretion in agalactic mares. Theriogenology $25,575-580$

Thompson DL Jr, Rhamanian MS, De Pew CL, Burleigh DW, De Souza CJ, Colborn DR (1992) Growth hormone in mares and stallions: pulsatile secretion, response to growth hormone releasing hormone and effects of exercise, sexual stimulation and pharmacological agents. J Anim Sci 70, 1201-1207

Tsushima T, Friesen HG (1973) Radioreceptorassay for growth hormone. J Clin Endocrinol Metab 37, 334 
Wallace JM, Martin GB, McNeilly AS (1988) Changes in the secretion of LH, FSH and PRL during the preovulatory phase of the oestrus cycle of the ewe and the influence of treatment with bovine follicular fluid during the lutheal phase. J Endocrinol 116, 123-135

Wardlaw (1985) Practical Statistics for Experimental Biologists. John Wiley and Son, New York
Wiest JJ, Thompson JR (1987) Plasma PRL, LH and FSH concentrations after suckling in post partum mares. J Reprod Fertil 35 (suppl), 731-732

Worthy K, Escreet R, Renton JP, Eckersall PD, Douglas TA, Flint DJ (1986) Plasma PRL concentrations and cyclic activity in pony mares during parturition and early lactation. J Reprod Fertil 77, 569-574 